\title{
Scalp hair analysis as a tool in assessing human exposure to heavy metals (S. Domingos mine, Portugal)
}

\author{
R. Pereira ${ }^{\mathrm{a}, \mathrm{b}, *}$, R. Ribeiro ${ }^{\mathrm{c}}$, F. Gonçalves ${ }^{\mathrm{a}}$ \\ a'Departamento de Biologia da Universidade de Aveiro, Campus Universitário de Santiago, 3810-193 Aveiro, Portugal \\ bInstituto Piaget, Campus Académico de Viseu, Estrada do Alto do Gaio, Lordosa, 3510-651 Viseu, Portugal \\ ${ }^{\mathrm{c}}$ Instituto do Ambiente e Vida, Departamento de Zoologia da Universidade de Coimbra, Largo Marquês de Pombal, \\ 3004-517 Coimbra, Portugal
}

Received 4 September 2003; accepted 13 January 2004

\begin{abstract}
Hair samples from the scalp were used in a preliminary assessment of heavy metals exposure ( $\mathrm{As}, \mathrm{Cd}, \mathrm{Cr}, \mathrm{Cu}, \mathrm{Mn}$ and $\mathrm{Zn}$ ) of the human population living near an abandoned cupric pyrite mine (Mina de S. Domingos, Southeast Alentejo, Portugal). In parallel with the collection of hair samples, individuals from two different communities at the South and North of the mine area answered a questionnaire designed to obtain information about potential exposure pathways to these elements. The questionnaire allowed data collection about the most frequently consumed foodstuffs, drinking water sources, smoking habits, alcohol consumption and health condition. Higher concentrations, and subsequently higher ranges, of $\mathrm{Cd}, \mathrm{Cu}$ and As were recorded in individuals living near the mine (MSD group), in opposition to individuals living several kilometers apart. Additionally, the concentrations recorded in the hair of some individuals from the MSD group were above the reference values for non-exposed individuals, suggesting their enhanced exposure. However, no significant differences were found for the average concentration of these elements between villages. Individuals from the $\mathrm{CP}$ and $\mathrm{SC}$ groups presented significantly higher concentrations of $\mathrm{Zn}$ and $\mathrm{Mn}$ in scalp hair. These results were in agreement with the concentrations of these elements recorded in soil samples. The water supplies of the area do not seem to be potential sources of trace elements for human beings. In opposition, individuals that frequently consume milk and cheese obtained from cattle that usually breeds in the area presented significantly higher concentrations of $\mathrm{As}$ and $\mathrm{Mn}$ in their scalp hair. Our results suggest that the population of $\mathrm{S}$. Domingos mine area and neighbour localities may be exposed to some of the elements analysed namely $\mathrm{Mn}$ and $\mathrm{Zn}$. The most likely exposure pathways seemed to be animal foodstuffs, however, a more detailed analysis of these products, as well as garden vegetables and fruits, should be performed.
\end{abstract}

(c) 2004 Elsevier B.V. All rights reserved.

Keywords: Hair; Heavy metals; Questionnaire; Exposure assessment; Contaminated sites

\footnotetext{
*Corresponding author. Tel.: +351-234370200Ext.22712; fax: +351-234370777.

E-mail address: ruthp@bio.ua.pt (R. Pereira).
} 


\section{Introduction}

Trace element analysis on hair samples has been widely used to assess wildlife (Madsen and Mason, 1987; Stevens et al., 1997) and human exposure to different contaminants present in the environment (Schuhmacher et al., 1991; Wilhelm et al., 1994; Schuhmacher et al., 1996; Sen and Chaudhuri, 1996) or at the workplace (Jamall and Jaffer, 1987; Ashraf et al., 1994). Several advantages were mentioned for the use of this biological material in monitoring studies (Okamoto et al., 1985; Dörner, 1988; Bencze, 1990; Kruse-Jarres, 2000; Wenning, 2000; ATSDR 2001), namely: (i) the less invasive character of hair collection procedures that avoid veninpucture; (ii) the stability of hair, as a biological material, which facilitates the storage and transport processes; (iii) the higher concentrations of residues usually found in hair samples, when compared to those on blood and urine, and (iv) the capacity of hair to accumulate metals during extended periods, reflecting by this way, at least 1 year of exposure. In opposition, some limitations were described for hair analysis, mainly the occurrence of exogenous contamination that contributes to a differential increase in the total contents of different contaminants (ATSDR, 2001; Frisch and Schwartz, 2002). The main sources of exogenous contaminants are deposits of sebum, sweat, polluted air residues or residues of cosmetic or pharmaceutical products (Kruse-Jarres, 2000). Some other constraints were pointed out for the use of hair analysis (ATSDR, 2001; Seidel et al., 2001; Harkins and Susten, 2003), namely: (i) the lack of correlation between concentrations of trace elements in hair and in other target organs (e.g. liver, kidney), or body fluids (e.g. blood, urine); (ii) the lack of scientific knowledge about kinetics of incorporation of trace elements in hair and; (iii) the insufficiency of epidemiological data to support predictions of health effects, related with a specific concentration of each element, in hair. In spite of these constraints, scalp hair has been considered a good screening tool to assess the likely occurrence of environmental exposures and to justify more extensive and expensive studies including all the population of concern (Bozsai, 1992; Masters, 2003).
With the perfect notion of all the advantages and disadvantages of using hair samples, this biological material was considered for a first step in the human exposure assessment of the human health risk assessment process of an abandoned cupric pyrite mine area, in Southeast Alentejo, Portugal (Pereira et al., in press). The aim of this study was to investigate the potential exposure of the human population living in the vicinity of the mine and to gain some insights about likely exposure pathways. Concentrations of toxic elements $\mathrm{As}, \mathrm{Cd}, \mathrm{Pb}$ and of essential metals such as $\mathrm{Cr}, \mathrm{Cu}$, $\mathrm{Mn}$, and $\mathrm{Zn}$ were analysed in hair samples of people living at different distances from the mine.

\section{Material and methods}

\subsection{Study area}

S. Domingos mine is an abandoned cupric pyrite mine located in the Southeast Alentejo, Portugal (Fig. 1). The ore extracted from the mine, during almost one century, near a village with the same name-Mina de S. Domingos-was treated there and in the sulfur mill area. After the treatment, it was transported by train to a harbour, in the Guadiana River, located in a small villagePomarão-approximately at $17 \mathrm{~km}$, and exported to England by boat. Mining activities ceased in 1965 and since then no reclamation measures were taken. Tons of mining tailings and several ponds filled with aqua fortis, both with high levels of heavy metals and arsenic, were left in the area, deeply transformed by past mining activities (Lopes et al., 1999; Pereira et al., 2000). Nowadays, these wastes continue to give rise to an acid mine drainage effluent that flows to the South and joins the Chança Reservoir, near the English dam (Pereira et al., in press) (Fig. 1). Widely scattered in the area, small human populations are potentially exposed to these environmental health hazards.

Total metals concentration, $\mathrm{pH}$, organic matter and conductivity, in surface soils $(10 \mathrm{~cm})$, were assessed at different distances from the mine (Pereira et al., submitted) (Table 1). Higher concentrations of $\mathrm{As}, \mathrm{Cu}, \mathrm{Fe}$ and $\mathrm{Pb}$ were recorded near the mine. As, $\mathrm{Cd}$ and $\mathrm{Cr}$ were above toxic 

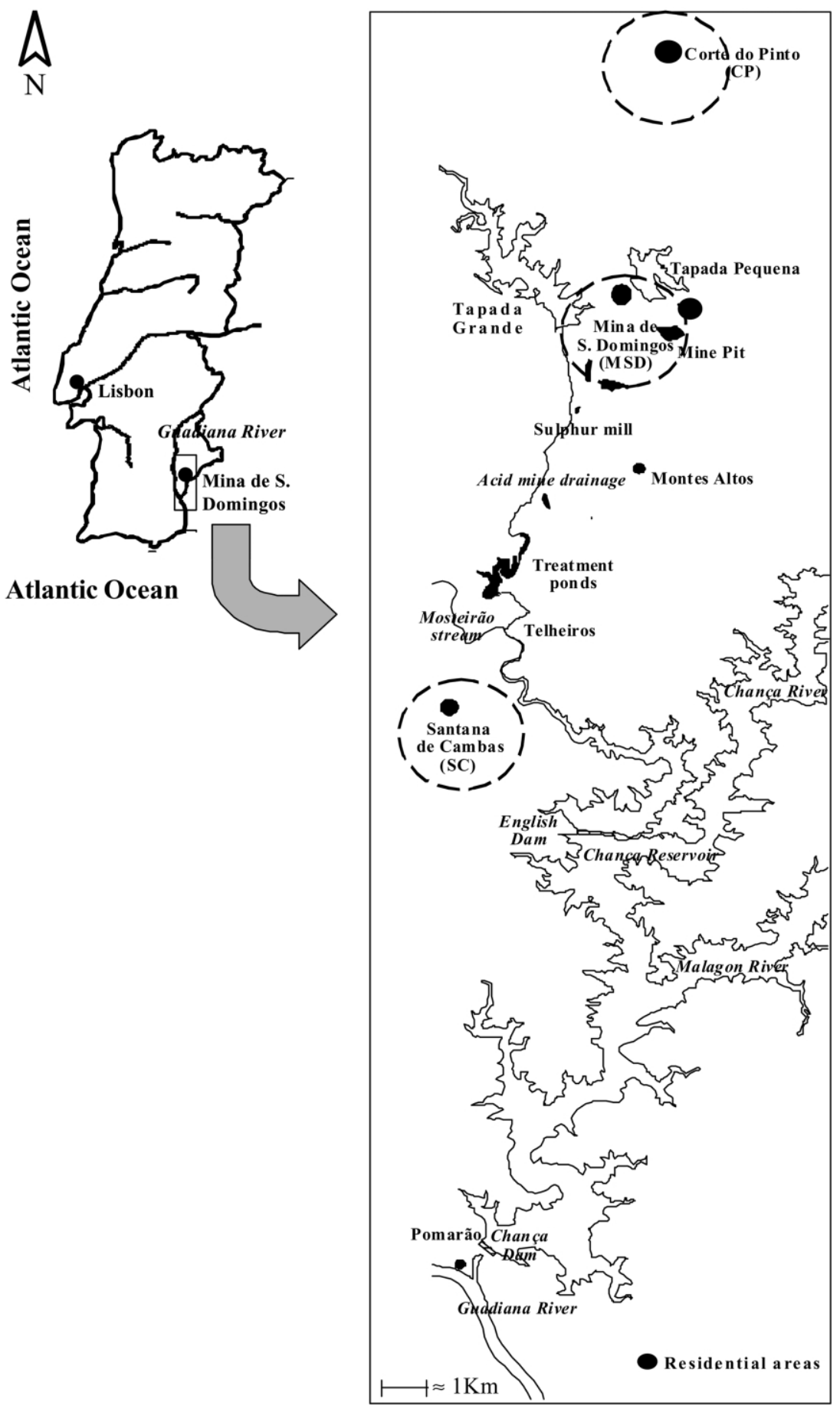

Fig. 1. Map of the study area. 
Table 1

Total metal concentrations $(\mathrm{mg} / \mathrm{kg}$, dry weight) in soil samples collected at different localities in the S. Domingos mine area (CP, MSD and SC) (Pereira et al., submitted)

\begin{tabular}{lrrrrrrrrrrrr}
\hline & $\mathrm{Fe}^{*}$ & $\mathrm{Cu}$ & $\mathrm{Cr}$ & \multicolumn{1}{c}{$\mathrm{Zn}$} & $\mathrm{Pb}$ & $\mathrm{Ni}$ & $\mathrm{Mn}$ & $\mathrm{As}$ & $\mathrm{Cd}$ & $\mathrm{pH} \pm \mathrm{STDEV}$ & Cond. \pm S.D. & OM (\%) \pm S.D. \\
\hline $\mathrm{CP}$ & 45 & 31 & 288 & 50 & 18 & 38 & 739 & $<20$ & 2 & $6.4 \pm 0.7$ & $33.6 \pm 8.5$ & $4.0 \pm 0.5$ \\
$\mathrm{MSD}$ & 49 & 281 & 114 & 108 & 1124 & 11 & 156 & 306 & 1 & $4.7 \pm 0.7$ & $74.7 \pm 39.8$ & $5.8 \pm 1.8$ \\
$\mathrm{SC}$ & 39 & 222 & 190 & 421 & 403 & 23 & 639 & 37 & 0.5 & $7.5 \pm 1.0$ & $99.3 \pm 51.2$ & $6.6 \pm 2.8$ \\
\hline
\end{tabular}

Cond. - Conductivity expressed in $\mu \mathrm{S} / \mathrm{cm}$.

$\mathrm{OM}$ - Organic matter.

CP (Corte do Pinto) - locality in the North of the mine; MSD (Mina de S. Domingos) - mining area; SC (Santana de Cambas) - locality in the South of the mine.

"Total Fe concentrations in soil samples are expressed in $\mathrm{g} / \mathrm{kg}$, dry weight.

levels, according to the soil quality criteria recommend by some European countries (MEE and DEPA, 1995), near the mine and also in the CP area, for the last two metals. Moreover, the low $\mathrm{pH}$ values and the high conductivity values recorded by Pereira et al. (1999) in preliminary studies, and confirmed later, especially for $\mathrm{pH}$ (Table 1), suggested a great bioavailability of metals and arsenic in the vicinity of mine. Although uncertain, the low organic matter contents could also contribute for a great bioavailability of trace elements, since the metal adsorption capacity decreases (Rieuwerts et al., 1998a,b).

\subsection{Samples collection and analysis}

Hair samples (ranging from 100 to $300 \mathrm{mg}$ ) were collected near the scalp, in order to reduce the contribution of exogenous contamination, from 29 inhabitants of the S. Domingos mine village (MSD) and 13 from Corte do Pinto (CP) village. Ten further samples were collected from inhabitants of Santana de Cambas (SC) village (Fig. 1). All the participants gave their permission to participate in the study. Regarding children, fathers gave written permission, after being clearly informed about the objectives of the study. In parallel, individuals were invited to answer a small questionnaire designed to obtain information about age, sex, food ingestion (home grown fruits and vegetables, fish and game animals, breeding cattle and canned food), source of consumed water, smoking habits, alcohol consumption, health condition and medication, and workplace. The questionnaire was adapted in order to make it friendlier for children. Samples were collected near the scalp with stainless steel scissors and put in polythene bags, closed with a zipper and immediately transported to the laboratory and stored at $-20{ }^{\circ} \mathrm{C}$. Each sample bag and the questionnaire received the same code. Only hair samples with their natural colour and from individuals residing permanently in the study area were considered for analysis.

Prior to chemical analysis hair samples were cut in small pieces $(2-3 \mathrm{~mm})$ and washed five times, according to the method proposed by IAEA (1977 in Subramanian, 1996), following the sequence acetone - Milli Q water ${ }^{\circledR}$-Milli Q water ${ }^{\circledR}$-Milli Q water $^{\circledR}$ - acetone (extra pure, Merck). Hair samples were immersed in $25 \mathrm{ml}$ of acetone or water, each time, during 20 min with magnetic stirring. Washed samples were oven-dried at $60{ }^{\circ} \mathrm{C}$ for 24 $\mathrm{h}$ and then weighed. The washing step is controversial (Bozsai, 1992; Subramanian, 1996), however, the removal of exogenous dirt, dead epithelial cells and sweat is crucial in the analysis of hair samples. Acetone is one of the most used organic solvents (Subramanian, 1996).

For wet ashing, $2 \mathrm{ml}$ of $\mathrm{HNO}_{3}(65 \%$ nitric acid, Suprapur, Merck) were added to each sample, in graduated polypropilene tubes. Tubes were screwcapped and the acid was allowed to react in a sand bath at approximately $60{ }^{\circ} \mathrm{C}$. Samples were allowed to cool and dropwise addition of $1 \mathrm{ml}$ aliquots of $\mathrm{H}_{2} \mathrm{O}_{2}$ (30\%, GR ISO for analysis, Merck) was made until a clear solution was obtained. Samples were diluted to a final volume using Milli-Q water ${ }^{\circledR}$. Sample blanks were prepared following the same procedure. Wet ashing was considered an appropriate procedure for prep- 
aration of biological samples for chemical analysis since it is performed at relatively low temperature reducing the possibility of analyte loss, especially the most volatile ones (Miller-Ihli, 1989; Hoenig and Kersabieck, 1996).

Standards were prepared using stock solutions Specpur $1000 \mu \mathrm{g} / \mathrm{ml}$ (Alfa Aesar, Johnson Mattey Company). Dilutions were made using $\mathrm{HNO}_{3}$ at $2 \%$. For each element three standards were used to cover the analytical working range of the instrument. Milli-Q water ${ }^{\circledR}$ was used for the preparation of calibration standards and blank. Three replicate determinations were performed for each sample. Due to the lack of certified hair standards for the validation of the analytical technique (Seidel et al., 2001), the standard addition method was performed in some additional hair samples, which were exactly submitted to the same digestion procedure of the other samples. Recovery of the known amounts of trace elements added to the hair samples, before wet ashing, varied between 85 and $106 \%$.

All the laboratory vessels used were washed with distilled water then soaked overnight in $50 \%$ $(\mathrm{v} / \mathrm{v})$ nitric acid. Finally, before use they were rinsed in Milli-Q water ${ }^{\circledR}$ and oven-dried.

An Atomic Absorption Spectrometer, GBC model 932 Plus, was used for flame atomic absorption analysis of $\mathrm{Zn}$. For graphite furnace analysis of $\mathrm{As}, \mathrm{Cd}, \mathrm{Cr}, \mathrm{Cu}, \mathrm{Mn}$ and $\mathrm{Pb}$, the apparatus was equipped with a GBC-GF3000 grafite furnace, a deuterium background correction and with a furnace autosampler PAL 3000. A Ni( $\left.\mathrm{NO}_{3}\right)_{2} /$ $\mathrm{Mg}\left(\mathrm{NO}_{3}\right)_{2}$ and diammonium hydrogen phosphate (1\%) were used as matrix modifiers to thermally stabilise $\mathrm{As}$ and $\mathrm{Pb}$, respectively (Krynitsky, 1987).

\subsection{Statistical analysis}

Questionnaires provided information about the following variables: age, sex, residence, the most consumed foodstuffs and the source of drinking water. Four age classes were considered: (i) $\leq 15$ years old; (ii) 16-25-years old; (iii) 26-45-years old and; (iv) $\geq 46$-years old. The first age class includes all the children and only one boy with 11-years old. Information about food and drinking water sources was obtained through multiplechoice questions. With respect to the kind of foodstuffs locally produced and more frequently ingested, the options of a multiple choice question were coded with one or zero if they were marked by the individuals or not, respectively. Based on this, two groups were considered for each option and the analysis was performed individually for each one. Regarding the source of drinking water, the options were: (i) bottled water; (ii) water from wells; and (iii) municipal water. The first option received a zero score, while the other two received a score of one and two, respectively. Therefore, four groups were defined including: (i) individuals that only consumed bottled water (scored with zero); (ii) individuals that chose one of the other two options (scored with one or two) and at least, (iii) individuals that chose both options (scored with three). Data about health condition and medicaments consumed, workplace, smoking habits and alcohol consumption were analysed only qualitatively.

For comparison of trace element concentrations, between different groups of individuals, One-way ANOVAs were used. In order to meet the purposes of this statistical procedure, data were transformed using the equation: $x^{\prime}=\log (x+1)$ (Zar, 1996). Whenever null hypothesis was rejected, a multiple comparison test (Tukey test) was used following ANOVA, to determine which groups of individuals differed from each other (Zar, 1996).

Pearson's correlation coefficient $(r)$ was calculated to investigate relationships between arsenic and metals concentrations recorded in the scalp hair. Linear regression analysis was performed to quantify relationships between levels of trace elements in the scalp hair and that age of individuals.

\section{Results and discussion}

Table 2 summarizes the results obtained for the five heavy metals and arsenic measured in the scalp hair samples collected. A distinction was made in the table between children and adults because in the South locality no children were included in the study. This can be explained by the fact that this is a very impoverished region of the country due to the lack of industrial and 
Table 2

Heavy metal concentrations in the scalp hair of adults and children from MSD, CP and SC

\begin{tabular}{|c|c|c|c|c|c|c|}
\hline & & \multicolumn{2}{|l|}{ Children } & \multicolumn{3}{|l|}{ Adults } \\
\hline & & MSD & $\mathrm{CP}$ & MSD & $\mathrm{CP}$ & $\mathrm{SC}$ \\
\hline $\mathrm{Zn}$ & $\begin{array}{l}\text { Average } \pm \text { S.E.M. } \\
n \\
\text { Concentr. range } \\
\text { Reference values }\end{array}$ & $\begin{array}{c}0.132 \pm 0.019 \\
9 \\
0.089-0.277 \\
0.054-0.327^{*}\end{array}$ & $\begin{array}{c}0.111 \pm 0.016 \\
3 \\
0.083-0.139\end{array}$ & $\begin{array}{c}0.410 \pm 0.117 \\
20 \\
0.117-2.042\end{array}$ & $\begin{array}{c}0.282 \pm 0.048 \\
9 \\
0.069-0.526\end{array}$ & $\begin{array}{c}0.240 \pm 0.030 \\
10 \\
0.102-0.407\end{array}$ \\
\hline $\mathrm{Mn}$ & $\begin{array}{l}\text { Average } \pm \text { S.E.M. } \\
n \\
\text { Concentr. range } \\
\text { Reference values }\end{array}$ & $\begin{array}{c}1.199 \pm 0.256 \\
9 \\
0.451-2.83 \\
0.04-24^{*}\end{array}$ & $\begin{array}{c}11.197 \pm 5.009 \\
3 \\
1.198-16.728\end{array}$ & $\begin{array}{c}2.606 \pm 1.038 \\
20 \\
0.022-19.62\end{array}$ & $\begin{array}{c}2.988 \pm 1.074 \\
9 \\
0.056-12.476\end{array}$ & $\begin{array}{c}10.806 \pm 3.417 \\
10 \\
0.023-35.481\end{array}$ \\
\hline $\mathrm{Cu}$ & $\begin{array}{l}\text { Average } \pm \text { S.E.M. } \\
n \\
\text { Concentr. range } \\
\text { Reference values }\end{array}$ & $\begin{array}{c}10.833 \pm 1.305 \\
9 \\
5.27-18.045 \\
6-293 *\end{array}$ & $\begin{array}{c}7.705 \pm 2.789 \\
3 \\
3.782-13.102\end{array}$ & $\begin{array}{c}27.188 \pm 11.488 \\
20 \\
0.452-208.818\end{array}$ & $\begin{array}{c}11.673 \pm 4.035 \\
9 \\
0.306-25.334\end{array}$ & $\begin{array}{c}22.482 \pm 4.264 \\
10 \\
9.720-52.723\end{array}$ \\
\hline $\mathrm{Cd}$ & $\begin{array}{l}\text { Average } \pm \text { S.E.M. } \\
n \\
\text { Concentr. range } \\
\text { Reference values }\end{array}$ & $\begin{array}{c}0.183 \pm 0.056 \\
9 \\
0.089-0.616 \\
0.04-5.3^{*}\end{array}$ & $\begin{array}{l}0.120 \pm 0.033 \\
3 \\
0.065-0.18\end{array}$ & $\begin{array}{c}0.891 \pm 0.355 \\
20 \\
0.103-6.08\end{array}$ & $\begin{array}{c}0.624 \pm 0.364 \\
9 \\
0.19-2.492\end{array}$ & $\begin{array}{c}0.236 \pm 0.075 \\
10 \\
0.213-0.915\end{array}$ \\
\hline $\mathrm{Cr}$ & $\begin{array}{l}\text { Average } \pm \text { S.E.M. } \\
n \\
\text { Concentr. range } \\
\text { Reference values }\end{array}$ & $\begin{array}{c}0.950 \pm 0.522 \\
9 \\
0.122-5.034 \\
0.08-2.5^{*} \text { or } 0 .\end{array}$ & $\begin{array}{l}0.744 \pm 0.236 \\
3 \\
0.488-1.216 \\
1.0^{* *}\end{array}$ & $\begin{array}{c}0.883 \pm 0.193 \\
20 \\
0.015-3.432\end{array}$ & $\begin{array}{c}1.219 \pm 0.331 \\
9 \\
0.413-4.808\end{array}$ & $\begin{array}{c}0.556 \pm 0.062 \\
10 \\
0.228-0.812\end{array}$ \\
\hline As & $\begin{array}{l}\text { Average } \pm \text { S.E.M. } \\
n \\
\text { Concentr. range } \\
\text { Reference values }\end{array}$ & $\begin{array}{c}0.245 \pm 0.044 \\
9 \\
0.099-0.457 \\
0.03-25^{*}\end{array}$ & $\begin{array}{c}0.352 \pm 0.117 \\
3 \\
0.152-0.556\end{array}$ & $\begin{array}{c}0.834 \pm 0.202 \\
20 \\
0.041-3.074\end{array}$ & $\begin{array}{c}0.529 \pm 0.222 \\
10 \\
0.047-2.515\end{array}$ & $\begin{array}{c}0.523 \pm 0.221 \\
9 \\
0.107-2.108\end{array}$ \\
\hline
\end{tabular}

*Caroli et al., 1994; **Katz and Salem, 1994.

$\mathrm{Zn}$ concentrations ( $\mathrm{mg} / \mathrm{g}$ of hair, dry weight).

$\mathrm{Mn}, \mathrm{Cu}, \mathrm{Cd}, \mathrm{Pb}, \mathrm{Cr}$ and As concentrations ( $\mu \mathrm{g} / \mathrm{g}$ of hair, dry weight).

CP (Corte do Pinto) - locality in the North of the mine; MSD (Mina de S. Domingos) - mining area; SC (Santana de Cambas) - locality in the South of the mine.

agriculture investment, therefore, the emigration of young people left behind an old population. A slightly different situation was found in $\mathrm{CP}$ and MSD, which were the main villages of the area with 337 and 800 inhabitants, respectively (INE, 1991). Having this problem in mind, statistical analysis was performed for adults alone and for adults and children grouped (Tables $3 a$ and $3 b$ ). Regarding occupation, a great majority of the individuals were students, retired or unemployed people. The mentioned jobs by the other individuals did not suggest potential exposure to heavy metals at the workplace.

Higher average concentrations, and higher ranges of $\mathrm{As}, \mathrm{Cd}$ and $\mathrm{Cu}$, were recorded in the MSD group, in opposition to the $\mathrm{CP}$ group and to the SC group (Table 2). The opposite was observed for $\mathrm{Cr}$ average concentrations in the scalp hair, which was higher in the CP group (Table 2). This last result was in agreement with the high concentration of chromium recorded in soil at this site (Table 1). However, for these four elements, the differences were not statistically significant, with respect to the place of residence of individuals. Additionally, the concentrations of $\mathrm{Cd}$ and $\mathrm{Cr}$ recorded in some individuals from the MSD group were above the reference values mentioned for hair samples, suggesting the exposure of these individuals and indicating that long-term health effects cannot be ruled out (Caroli et al., 1994; 
Table 3a

Significant statistical results for essential trace element concentrations in hair samples of the different groups of individuals

\begin{tabular}{|c|c|c|c|c|c|}
\hline Element & Factor & $n$ & Average conc. in hair \pm S.E.M. & $F$ & $P$ \\
\hline $\mathrm{Mn}$ & Residence $(A+C)$ & & & & \\
\hline \multirow[t]{18}{*}{ ( $\mu \mathrm{g} / \mathrm{g}$ dry weight) } & $\mathrm{CP}$ & 12 & $5.040 \pm 1.873$ & & \\
\hline & MSD & 29 & $0.655 \pm 0.130$ & & \\
\hline & $\mathrm{SC}$ & 10 & $5.368 \pm 3.417$ & 4.050 & 0.024 \\
\hline & Sex (adults) & & & & \\
\hline & M & 22 & $1.317 \pm 0.485$ & & \\
\hline & $\mathrm{F}$ & 17 & $6.100 \pm 2.224$ & 5.579 & 0.024 \\
\hline & Frequently consumed f & is $(\mathrm{A}$ & & & \\
\hline & Milk and cheese & & & & \\
\hline & Yes & 9 & $8.069 \pm 4.116$ & & \\
\hline & No & 30 & $2.003 \pm 0.479$ & 6.631 & 0.014 \\
\hline & Honey & & & & \\
\hline & Yes & 13 & $6.758 \pm 2.928$ & & \\
\hline & No & 26 & $1.724 \pm 0.425$ & 5.587 & 0.023 \\
\hline & Drinking water source & & & & \\
\hline & Bottled water & 8 & $10.329 \pm 4.249$ & & \\
\hline & Water from wells & 16 & $2.175 \pm 0.816$ & & \\
\hline & Municipal water & 12 & $1.018 \pm 0.250$ & & \\
\hline & $\begin{array}{l}\text { Water from wells } \\
\text { and municipal water }\end{array}$ & 3 & $1.011 \pm 0.525$ & 4.874 & 0.006 \\
\hline \multirow{7}{*}{$\begin{array}{l}\mathrm{Zn} \\
\text { (mg/g dry weight) }\end{array}$} & Residence $(\mathrm{A}+\mathrm{C})$ & & & & \\
\hline & $\mathrm{CP}$ & 12 & $0.239 \pm 0.045$ & & \\
\hline & MSD & 29 & $0.324 \pm 0.084$ & & \\
\hline & $\mathrm{SC}$ & 10 & $5.368 \pm 3.417$ & 4.691 & 0.014 \\
\hline & $\operatorname{Sex}(A)$ & & & & \\
\hline & M & 22 & $0.222 \pm 0.023$ & & \\
\hline & $\mathrm{F}$ & 17 & $0.486 \pm 0.132$ & 4.899 & 0.033 \\
\hline \multirow{3}{*}{ ( $\mu \mathrm{g} / \mathrm{g}$ dry weight) } & $\operatorname{Sex}(A+C)$ & & & & \\
\hline & M & 26 & $1.186 \pm 0.238$ & & \\
\hline & $\mathrm{F}$ & 25 & $0.566 \pm 0.133$ & 5.054 & 0.029 \\
\hline
\end{tabular}

A + C - Adults and children; A - adults.

CP (Corte do Pinto) - locality in the North of the mine; MSD (Mina de S. Domingos) - mining area; SC (Santana de Cambas)

- locality in the South of the mine.

Katz and Salem, 1994). However, some caution should be taken when comparing our results with reference values for hair residues, due to the great variability that usually exists between different laboratories (Kruse-Jarres, 2000; ATSDR, 2001; Seidel et al., 2001). When reference ranges established for a particular element are surpassed it cannot be concluded with security that the individuals were exposed to a toxic concentration of the element (ATSDR, 2001).

Statistically significant differences for $\mathrm{Mn}$ and $\mathrm{Zn}$ concentrations in scalp hair were found for the three groups defined according to the place of residence (Table 3a). Interestingly, the highest average concentration of $\mathrm{Mn}$ was recorded in inhabitants from CP and SC localities, precisely where the highest concentration of this metal was recorded in the soil (Table 1). With respect to $\mathrm{Zn}$ concentrations, the Tukey multiple comparison test showed significant differences between the SC group and the MSD and the $\mathrm{CP}$ groups. $\mathrm{Zn}$ concentrations were also higher in soil samples collected in the SC area and near the sulphur mill (Fig. 1), however, people live at some distance from this abandoned industrial plant. A positive correlation coefficient was also found between $\mathrm{Mn}$ and $\mathrm{Zn}$ contents in hair samples $(r=0.793, P<$ $0.001)$. Mn and $\mathrm{Zn}$ are essential elements, there- 
Table 3b

Significant statistical results for non-essential trace element concentrations in hair samples of the different groups of individuals

\begin{tabular}{llrlr}
\hline Element & Factor & $n$ & Average conc. in hair \pm S.E.M. & $F$ \\
\hline Cd & Age $(\mathrm{A}+\mathrm{C})$ & & & \\
( $\mu \mathrm{g} / \mathrm{g}$ dry weight $)$ & $\leq 15$ years & 13 & $0.172 \pm 0.039$ & \\
& $16-25$ & 8 & $0.520 \pm 0.106$ & 3.501 \\
& $26-45$ & 9 & $1.519 \pm 0.750$ & 0.023 \\
& $>45$ years & 21 & $0.468 \pm 0.111$ & \\
As & Frequently consumed foodstuffs $(\mathrm{A})$ & & \\
$(\mu \mathrm{g} / \mathrm{g}$ dry weight $)$ & Milk and cheese & 10 & $1.032 \pm 0.373$ & 0.034 \\
& Yes & 41 & $0.478 \pm 0.089$ & \\
\hline
\end{tabular}

$\mathrm{A}+\mathrm{C}-$ Adults and children; $\mathrm{A}-$ adults.

fore, their co-occurrence in the scalp hair of individuals should be considered normal. However, the statistically significant differences recorded for the concentrations of these elements, based on the place of residence, as also as the occurrence of As and $\mathrm{Cd}$ (non-essential elements) in hair samples, suggested environmental exposure.

Even though manganese and zinc are essential elements, high levels of these elements may yield adverse health effects. According to ATSDR (1994) and USEPA (1991), zinc components found at hazardous waste sites may cause: (i) decrease in serum HDL cholesterol levels and, subsequently, an increased risk of coronary artery disease; (ii) gastrointestinal irritation; (iii) anemia due to zinc-induced copper deficiency; (iv) pancreatic and adrenal gland damage; (v) alteration in the serum lipid profile, and (vi) pituitary hyperactivity. Regarding Mn, the high levels usually recorded in hazardous waste sites may be of potential concern for people living in the vicinity (ATSDR, 2000). The central nervous system (mainly globullus pallidus) is the primary target for Mn toxicity, either trough a manganese-induced formation of reactive oxygen species, as a result of the oxidation of dopamine or other cathecolamines, or by inhibition of the mithocondrial oxidative phosphorylation (ATSDR, 2000; USEPA, 2002). Environmental concentrations of Mn may also induce musculoskeletal effects and decreases in reproductive hormones with some subsequent physiological changes, such as loss of libido and impotence in men and also infertility and changes in menstrual cycles in women (USEPA, 1988; ATSDR, 2000). However, Mn is considered the least toxic of the trace elements when exposure occurs via ingestion (ATSDR, 2000).

Regarding $\mathrm{Pb}$, it was recorded only in six adults and four children, all the other hair samples presented concentrations below the detection limit. The greatest concentration $(54.112 \mu \mathrm{g} / \mathrm{g})$ was recorded in a MSD resident though, this individual mentioned smoking 60 cigarettes per day. Additionally, all the $\mathrm{Pb}$ concentrations recorded in hair samples were within the reference concentration range reported for this element in hair (0.004-95 $\mu \mathrm{g} / \mathrm{g}$ ) (Caroli et al., 1994). Thus, $\mathrm{Pb}$ content in hair samples did not suggest the exposure of individuals to this element.

All the individuals with the highest concentrations of the trace elements, in scalp hair, consumed one or more of these products: water from wells, garden fruits and vegetables, breeding cattle and fish caught in local water resources. Individuals who frequently consume milk and cheese produced locally had significantly higher concentrations of As in scalp hair (Table 3b). Considering only adults, a similar result was recorded with respect to Mn concentrations. Those mentioning the frequent consumption of milk and cheese and also honey presented significantly higher concentrations of Mn on their hair (Table 3a). Additionally, individuals who frequently consumed meat from locally bred cattle presented higher average concentrations of $\mathrm{As}, \mathrm{Cr}, \mathrm{Cu}$ and $\mathrm{Zn}$, however, no significant differences were found when compared 
with individuals that did not refer this foodstuff. In fact, several inhabitants of MSD area had their own cattle, mainly sheep, and usually left them graze in the vicinity of the abandoned mine area. As several authors have shown, livestock species exposed to environmental concentrations may accumulate heavy metals on different tissues (Leita et al., 1991; Alonso et al., 2000, 2002) whereas milk is an excretion pathway of contaminants from the body (Zumkley and Spieken, 1988; USEPA, 1993). Although no significant differences were found, individuals that frequently consumed garden vegetables and fruits presented higher levels of $\mathrm{Cu}$ and $\mathrm{Zn}$ on their hair. The same trend was observed with respect to $\mathrm{Mn}$ and As levels when the consumption of fish was analysed, however, any significant differences were found. Fishing is a recreational activity for the inhabitants of $\mathrm{S}$. Domingos mine area therefore fish caught in local water resources is sporadically consumed.

According to our results, there is no evidence that the water supplies of the area works as a potential source of heavy metals and arsenic for humans, because no significant differences were found between groups of individuals based on the source of drinking water, for all the elements analysed, except for manganese (Table 3a). Regarding this element, the results were somewhat surprising, since the group that mentioned to consume only bottled water presented the highest concentrations of $\mathrm{Mn}$ in the scalp hair (Table 3a).

Hair concentrations of $\mathrm{Mn}$ and $\mathrm{Zn}$ were significantly higher for women than for men (children not included) (Table 3a). Ping and Xingquan (1993) and Nowak and Chmielnicka (2000) observed the same trend for these metals. The gender is one of the factors that may influence the potential for adverse health effects yielded by heavy metals (ATSDR, 1994).

In agreement with other authors (e.g. Ashraf et al., 1994), the regression analysis did not show any relationship between the individual's age and the concentration of the different metals in their hair samples. However, for cadmium concentrations in scalp hair, significant differences were found between age classes. The Tukey multiple comparison test showed that individuals less than 15 years old presented significantly lower concen- trations of this element when compared with those between 26 and 45 years (Table 3b). A qualitative analysis of the questionnaire data demonstrated that within the oldest individuals, three of them smoke and one mentioned living with smoking parents. However, from these individuals only one was among the highest concentrations of cadmium recorded in scalp hair samples of the group. Additionally, any of these individuals might have been subjected to occupational exposure to $\mathrm{Cd}$. Therefore, these observations suggest an environmental origin of the $\mathrm{Cd}$ recorded on the scalp hair samples and were in agreement with the cumulative behaviour of this metal which has a long half life in the body (ATSDR, 1999). Individuals between 20 and 25 years are the ones where the cadmium concentration in the liver attains its highest value. The same phenomenon is observed in the kidney of individuals between 40 and 45 years. After these ages, cadmium concentrations usually stabilize or decrease (ATSDR, 1999). However, it is important to mention the great susceptibility of children, even to low levels of exposure, and likely occurrence of long-term health effects (ATSDR, 1999).

A large variability was observed for the concentrations of the six elements recorded in the hair samples collected in S. Domingos mine area. These results may be explained by the discontinuous growth of hair follicles, the different lengths of hairs sampled, in association with the increment of metals from roots to tips, as also with the relative permeability of hair epidermis which allows the immigration and deposition of chemicals in the internal molecular structure of hair (Kruse-Jarres, 2000; Wenning, 2000). This is a problem especially difficult to overcome when one is dealing with very short hairs and also with an old population, which prevents the elimination of unbleached hair from analysis.

In spite of the limited utility of hair analysis as a diagnostic and exposure assessment tool (Frisch and Schwartz, 2002), our results suggest that the population of $\mathrm{S}$. Domingos mine area may be exposed to some of the elements analysed, namely $\mathrm{Mn}$ and $\mathrm{Zn}$. This suspicion was in part supported by statistical analysis but also by the consistency between the results obtained by the scalp hair analysis and the concentrations recorded in soil 
samples. The most likely exposure pathways seemed to be animal products (breeding cattle), but a more detailed analysis of these foodstuffs and also of garden fruits and vegetables, should be performed. Although no statistically significant differences were found for the scalp hair levels between individuals that mentioned the more frequent consumption of these last food items, several authors have documented the bioaccumulation of heavy metals (e.g. cadmium) on different plant species (e.g. carrots, lettuce, potatoes), cultivated in contaminated soils, which may pose serious risks to humans (Förstner, 1980; Lee et al., 1999; Pinochet et al., 1999; Cobb et al., 2001).

Some attention should also be paid to the likely sub-estimation of the concentrations of some trace elements in scalp hair samples. This suspicion derives from the fact that although the washing procedure used in our study was proposed by the IAEA as a standard method, some authors have proved that it is not suitable for all the elements analysed (e.g. chromium) (Kumpulainen et al., 1982).

According to ATSDR (2001), the presence of a substance may indicate exposure, but not the source of exposure. However, we believe that the use of questionnaire data to define groups of individuals, which were statistically compared, gave some insights about some sources of exposure of the human population living in the S. Domingos mine area.

\section{Acknowledgments}

The authors are very grateful to A. Oliveira e Cruz and A. Panteleitchouck for the permission to use Atomic Absorption Spectrometer from the Instituto Piaget de Viseu, Portugal. We also thank to O. Sobral and S.C. Antunes by their support in the field and also to B. Castro to its helpful comments to improve the English language. This work was supported by a Ph.D. grant (Praxis XXI/BD/9008/96) from the Fundação para a Ciência e a Tecnologia.

\section{References}

Alonso ML, Benedito JL, Miranda M, Castillo C, Hernández $\mathrm{J}$, Shore RF. Toxic and trace elements in liver, kidney and meat from cattle slaughtered in Galicia (NW Spain). Food Addit Contam 2000;17(6):447-457.

Alonso ML, Benedito JL, Miranda M, Castillo C, Hernández J, Shore RF. Interactions between toxic and essential trace metals in cattle from a region with low levels of pollution. Arch Environ Contam Toxicol 2002;42:165-172.

Ashraf W, Jaffar M, Mohammad D. Trace metal contamination study on scalp hair of occupationally exposed workers. Bull Environ Contam Toxicol 1994;53:516-523.

ATSDR - Agency for Toxic Substances and Disease Registry. Toxicological Profile for Zinc. US Department of Health and Human Services. Public Health Service, 1994. Available at: http://www.atsdr.cdc.gov/toxprofiles/tp60.html, on-line at 25 June 2003.

ATSDR - Agency for Toxic Substances and Disease Registry. Toxicological Profile for Cadmium. US Department of Health and Human Services. Public Health Service, 1999. Available at: http://www.atsdr.cdc.gov/toxprofiles/ tp5.html, on-line at 25 June 2003.

ATSDR - Agency for Toxic Substances and Disease Registry. Toxicological Profile for Manganese. US Department of Health and Human Services. Public Health Service, 2000. Available at: http://www.atsdr.cdc.gov/toxprofiles/ tp151.html, on-line at 25 June 2003.

ATSDR - Agency for Toxic Substances and Disease Registry. Hair Analysis Panel Discussion: Exploring the State of the Science. June 12-13. Summary Report. Agency for Toxic Substances and Disease Registry, Division of Health Assessment and Consultation and Division of Health Education and Promotion. Atlanta, Georgia, 2001. Available at: http:/ /www.atsdr.cdc.gov/HAC/hair_analysis/, on line at 3 June 2003.

Bencze K. What contributions can be made to biological monitoring of hair analysis? Part 1. Fresen J Anal Chem 1990;337:867-876.

Bozsai G. Quality control and assurance in hair analysis. Microchem J 1992;46:159-166.

Caroli S, Alimonti A, Coni E, Petrucci F, Senofonte O, Violante N. The assessment of reference values for elements in human biological tissues and fluids: a systematic review. Crit Rev Anal Chem 1994;24(5-6):363-398.

Cobb GP, Sands K, Waters M, Wixson BG, Dorward-King E. Accumulation of heavy metals by vegetables grown in mine wastes. Environ Toxicol Chem 2001;19(3):600-607.

Dörner K. Trace element analysis of human hair. In: Grupe G, Herrman B, editors. Trace elements in the environmental history. Berlin, Hidelberg, Germany: Springer-Verlag, 1988. p. $113-123$.

Förstner U. Cadmium. In: Hutzinger O, editor. The handbook of environmental chemistry, part A. Anthropogenic compounds, vol. 3. Heidelberg, Germany: Springer-Verlag, 1980. p. $58-101$.

Frisch M, Schwartz BS. The pitfalls of hair analysis for toxicants in clinical practice: three case reports. Environ Health Perspect 2002;110(4):433-436.

Harkins DK, Susten AS. Hair analysis: exploring the state of science. Environ Health Perspect 2003;111(4):576-578. 
Hoenig M, Kersabieck AM. Sample preparation steps for analysis by atomic spectroscopy methods: present status. Spectrochim Acta 1996;51B:1297-1307.

INE (Instituto Nacional de Estatística). XIII Recenseamento Geral da População. III Recenseamento Geral da Habitação. INE, Lisboa, Portugal, 1991.

Jamall IS, Jaffer RA. Elevated iron levels in hair from steel mill workers in Karachi, Pakistan. Bull Environ Contam Toxicol 1987;39:608-614.

Katz SA, Salem H. The biological and environmental chemistry of chromium. New York, USA: VCH Publishers, 1994. p. 214.

Kruse-Jarres JD. Limited usefulness of essential trace element analysis in hair. Clinical Note. Proceedings of PITTCON ${ }^{\circledR}$, 98, New Orleans 2000, p. 1597.

Krynitsky AJ. Preparation of biological tissue for the determination of arsenic and selenium by graphyte furnace atomic absorption spectrometry. Anal Chem 1987;59:1884-1886.

Kumpulainen J, Salmela S, Vuori E, Lehto J. Effects of various washing procedures on the chromium content of human scalp hair. Anal Chem Acta 1982;138:361-364.

Lee YZ, Suzuki S, Kawada T, Wang J, Koyama H, Rivai IF. Content of cadmium in carrots compared with rice in Japan. Bull Environ Contam Toxicol 1999;63:711-719.

Leita L, Enne G, De Nobili M, Baldini M, Sequi P. Heavy metal bioaccumulation in lamb and sheep bred in smelting and mining areas of S.W. Sardinia (Italy). Bull Environ Contam Toxicol 1991;46:887-893.

Lopes I, Gonçalves F, Soares AMVM, Ribeiro R. Discriminating the ecotoxicity due to metals and to low $\mathrm{pH}$ in acid mine drainage. Ecotoxicol Environ Safe 1999;44:207-214.

Madsen AB, Mason CF. Cadmium, lead and mercury in hair from Danish otters Lutra lutra. Nat Jutl 1987;22(3):81-84.

Masters RD. Validity of head hair analysis and methods of assessing multiple chemical sensitivity, 2003. Available at: http://www.darthmouth.edu/ rmasters/Cree/Validity.htm, on line at 26 June 2003.

Miller-Ihli NJ. Graphite furnace atomic absorption spectrometry for the analysis of biological materials. Spectrochim Acta 1989;44B(12):1221-1227.

Nowak B, Chmielnicka J. Relationship of lead and cadmium to essential elements in hair, teeth and nails of environmental exposed people. Ecotoxicol Environ Safe 2000;46:265-274.

Okamoto K, Morita M, Quan H, Uehiro T, Fuwa K. Preparation and certification of human hair powder reference material. Clin Chem 1985;31(10):1592-1597.

Pereira R, Gonçalves F, Pereira ML, Ribeiro R. Análise de Risco para a saúde humana e vida selvagem em minas abandonadas (um caso de estudo). In: Actas da $6^{a}$ Conferência Nacional sobre a Qualidade do Ambiente, Lisboa, 1999, pp. 167-177.

Pereira R, Ribeiro R, Gonçalves F. Plan for an integrated human and environmental risk assessment in S. Domingos mine area (Portugal). In press in the $\mathrm{J}$ Hum Ecol Risk Assessment.
Pereira AMM, Soares AMVM, Gonçlaves F, Ribeiro R. Watercolumn, sediment and in situ chronic bioassays with cladocerans. Ecotoxicol Environ Safe 2000;47:27-38.

Ping S, Xingquan Z. Relationship between the elemental content and $\mathrm{pH}$ of human hair. Sci Total Environ 1993;128:151-156.

Pinochet H, De Gregori I, Lobos MG, Fuentes E. Selenium and copper in vegetables and fruits grown on long term impacted soils from Valparaiso Region, Chile. Bull Environ Contam Toxicol 1999;63:327-334.

Rieuwerts JS, Thornton I, Farago ME, Ashmore MR. Factors influencing metal bioavailability in soils: preliminary investigations for the development of critical loads approach for metals. Chem Spec Bioavailab 1998a;10(2):61-75.

Rieuwerts JS, Thornton I, Farago ME, Ashmore MR. Quantifying the influence of soil properties on the solubility of metals by predictive modelling of secondary data. Chem Spec Bioavailab 1998b;10(3):83-94.

Schuhmacher M, Domingo JL, Llobet JM, Corbella J. Lead in children's hair as related to exposure in Tarragona Province, Spain. Sci Total Environ 1991;104:167-173.

Schuhmacher M, Bélles M, Rico A, Domingo JL, Corbella J. Impact of reduction of lead in gasoline on the blood and hair lead levels in the population of Tarragona Province, Spain, 1990-1995. Sci Total Environ 1996;184:203-209.

Seidel S, Kreutzer R, Smith D, McNeel S, Gilliss D. Assessment of commercial laboratories performing hair mineral analysis. Jama 2001;285(1):67-72.

Sen J, Chaudhuri ABD. Human hair lead and copper levels in three occupationally unexposed population groups in Calcutta. Bull Environ Contam Toxicol 1996;57:321-326.

Stevens RT, Ashwood TL, Sleeman JM. Mercury in hair of muskrats (Ondatra zibethicus) and mink (Mustela vision) from the US Department of Energy Oak Ridge Reservation. Bull Environ Contam Toxicol 1997;58:720-725.

Subramanian KS. Determination of metals in biofluids and tissues: sample preparation methods for atomic spetroscopic techniques. Spectrochim Acta Part B 1996;51:291-319.

USEPA - United States Environmental Protection Agency. Manganese, 1988. Available at: http:/www.epa.gov/iris/ subst/0373/.htm.

USEPA - United States Environmental Protection Agency. Zinc and compounds, 1991. Available at: http:/ www.epa.gov/iris/subst/0426/.htm.

USEPA - United States Environmental Protection Agency. Wildlife Exposure Factors Handbook. Vol I. Environmental Protection Agency EPA/600/R-93/187. Office of Health and Environmental Assessment and Office of Research and Development, Washington DC 20460, 1993.

USEPA - United States Environmental Protection Agency. Health effects support document for manganese. External Review Draft. US Environmental Protection Agency, Office of Water. Health and Ecological Criteria Division, Washington, 2002.

Wenning R. Potential problems with the interpretation of hair analysis results. Forensic Sci Int 2000;107:5-12. 
Wilhelm M, Lombeck I, Ohnesorge FK. Cadmium, copper, lead and zinc concentrations in hair and toenails of young children and family members: a follow-up study. Sci Total Environ 1994;141:275-280.

Zar JH. Biostatistical analysis, 3rd ed. New Jersey: PrenticeHall International Inc, 1996. p. 662.
Zumkley H, Spieken L. The bioavailability of trace elements and age specific trace elements metabolism. In: Grupe G, Herrman B, editors. Trace elements in the environmental history. Berlin, Hidelberg, Germany: Springer-Verlag, 1988. p. $145-150$. 